\title{
EFFECT OF RED MULBERRY JUICE (MORUS RUBRA) ON THE INFLAMMATORY RESPONSE IN MALE WISTAR RATS DUE TO EXPOSURE TO CIGARETTE SMOKE
}

\author{
Rivan Virlando Suryadinata ${ }^{{ }^{*}}$, Merryana Adriani ${ }^{2}$, Stefani Cornelia Sardjono ${ }^{3}$ \\ ${ }^{1}$ Faculty of Medicine, University of Surabaya (UBAYA), Surabaya \\ ${ }^{2}$ Department of Nutrition, Faculty of Public Health, Universitas Airlangga, Surabaya \\ ${ }^{3}$ Students of the Medical Study Program, University of Surabaya (UBAYA), Surabaya \\ *E-mail: rivan.virlando.suryadinata@gmail.com
}

\begin{abstract}
The increasing number of tobacco users will directly impact to an increase in the number of passive smokers. Various harmful substances that enter the respiratory tract can cause health problems. The airway will recognize these substances as pathogen and activate immune response accordingly. Inflammatory response becomes one of the effects of body compensation due to an increased pathogen. This effect is indicated by the elevation of C-Reactive Protein as one systemic inflammatory response parameters in the body. This study aimed to determine the efficacy of red mulberry juice to reduce levels of C-Reactive Protein in Wistar rats because exposure to cigarette smoke. This is an experimental study with a post-test control group design. Animals were divided into negative control group, positive control group, and 3 treatment groups with different red mulberry doses. The positive control group showed the highest increase in C-Reactive Protein levels compared with the red mulberry intake group $(p<0,001)$. In conclusion, the administration of red mulberry juice can reduce inflammatory response in rats because of exposure to cigarette smoke.
\end{abstract}

Keywords: c-reactive protein, cigarette, inflammation, red mulberry

\section{INTRODUCTION}

Tobacco cigarettes are the most common type of cigarette used worldwide (Gowing et al., 2015). Various studies have shown the dangers of using tobacco cigarettes both as active smokers and passive smokers (Suryadinata et al., 2017). Smoking has caused 6 million people dies each year and it is estimated will reach 8 million in 2030. Globally, the number of tobacco smokers has reached 1.1 billion people and almost $70 \%$ are residents of developing countries (Nasser et al, 2018). The prevalence of active smokers in developed countries has shown a significant decrease. Estimated in 2015, number of smokers in developed countries like America and Europe was around $15 \%$ of total population (West, 2017). In developing countries, the number of smokers increases every year, especially in the productive age (Hossain et al., 2017).

Smoke contains more than 4000 types various ingredients, including nicotine, ammonia, phenols, polycyclic aromatics, carbon monoxide, nitrogen oxides, and various metals (Kamceva et al., 2016). Two main phases that can be identified in cigarette smoke are tar phase and gas phase. Both phases contain high free radicals such as superoxide (O2•-) and hydroxyl $(\bullet \mathrm{OH})$ (Suryadinata, 2018). Increased free radicals in body due to exposure to smoke cigarettes entering airways will cause oxidative stress and trigger lipid peroxidation. This will potentially cause cell damage and necrosis (Suryadinata et al., 2019). Normally, free radicals are mitochondrial metabolism and can be neutralized by enzymatic antioxidants in body (Suryadinata et al, 2019). In pathological conditions, excessive free radicals will directly stimulate inflammatory response through phagocytic process of macrophages (Arulselvan et al., 2016).

Inflammatory process is a form of body defence mechanism against pathogenic reactions from outside. Various pro-inflammatory cytokines are secreted into body microenvironment such as interleukin-1, interleukin-6, interleukin-8, and tumor necrosis factor-alpha (TNF- $\alpha$ ). Inflammatory mediator will induce liver to release C-Reactive Protein (CRP) into the blood (Phaniendra et al., 2015). Prevention of inflammatory process due to free radical increase in the body can be done with administration of antioxidants from the outside. 
Various types of non-enzymatic antioxidants can be obtained from food especially flavonoids (Pratiwi et al., 2018).

Mulberry fruit is one type of fruit that high in antioxidants. Mulberries originated from genus Morus of Moraceae family, to date there are 24 species and 100 varieties (Zhang et al., 2018). Various studies have shown the provision of mulberry fruit has potential impact as antioxidant (Zhang and Shi, 2010). This study used red mulberry juice (Morus rubra) juice to reduce body inflammatory response due to exposure to tobacco smoke. Besides, red mulberries are also widely planted and consumed by Indonesian people so that at the same time can preserve local food. This study purpose is to analyze the efficacy of red mulberry juice to reduce levels of C-Reactive Protein in Wistar rats exposed to cigarette smoke.

\section{METHODS}

This research was an experimental study with post-test control group design performed in 25 male Wistar rats (Rattus norvegicus) which were divided into 5 groups for 30 days. Inclusion criteria in this study were experimental animals aged 3-4 months with weight around $200 \mathrm{~g}$. While the exclusion criteria are animals get sick or die during study. Maintenance and care of the animals during study are based on 3R principles (Replacement, Reduction, and Refinement). This research has been obtained Ethical Clearance Certificate from Institutional Ethical Committee, University of Surabaya (No:135/KE/VI/2020).

Red mulberries (Morus rubra) that have been obtained, sorted and cleaned in order to get fruit in good condition. Red mulberry juice that has been obtained then performed flavonoid levels measurement $( \pm 38 \mathrm{mg} / \mathrm{g})$. Results of flavonoids levels that have been obtained then converted from daily needs of adults $( \pm 190 \mathrm{mg} / \mathrm{kg})$ into daily dose intake of Wistar rats with $200 \mathrm{~g}$ body weight $( \pm 240$ $\mathrm{mg} / \mathrm{rats}$ ) using Laurence and Bacharach table. The amount of red mulberry juice given orally to the treatment group was $3.25 \mathrm{~g}, 6.5 \mathrm{~g}$, and $13 \mathrm{~g}$.

The results of CRP level measurement are based on agglutination process in blood through intracardiac puncture. Dilution process show the results of C-Reactive Protein measurement i.e., >
$6 \mathrm{mg} / \mathrm{L}, 12 \mathrm{mg} / \mathrm{L}, 24 \mathrm{mg} / \mathrm{L}, 48 \mathrm{mg} / \mathrm{L}$ and $96 \mathrm{mg} / \mathrm{L}$. Measurement results were classified as positive if C-Reactive protein levels obtained more than $6 \mathrm{mg} / \mathrm{L}$, and negative if C-Reactive Protein level obtained were less than $6 \mathrm{mg} / \mathrm{L}$.

This research was conducted for 30 days by dividing rats into 5 groups. The first was the negative control group, where animals did not received any treatment. In positive control group, animals received daily intake and exposure to 2 tobacco cigarettes smoke per day in smoking chamber. While last three groups were exposed to 2 tobacco cigarettes smoke per day, daily intake, and $3.25 \mathrm{~g}, 6.5 \mathrm{~g}$, or $13 \mathrm{~g}$ red mulberry juice.

Results of study were ordinal data in the form of CRP levels in each group in $\mathrm{mg} / \mathrm{L}$ units. CRP measurement method uses dilution to get a multiple of the result. CRP levels of $>6 \mathrm{mg} / \mathrm{L}, 12$ $\mathrm{mg} / \mathrm{L}, 24 \mathrm{mg} / \mathrm{L}$ and $48 \mathrm{mg} / \mathrm{L}$ will be carried out for coding. Data analysis was performed using Kruskal Wallis analysis with SPSS version 22 to observe differences between groups.

\section{RESULTS AND DISCUSSIONS}

Results of study were carried out by comparing C-Reactive Protein levels between groups. Table 1. shows results of C-Reactive Protein level measurement in blood between group. Group I, IV, and V had the same levels of C-Reactive Protein. The highest level of C-Reactive Protein obtained in Group II which is the Positive Control Group.

Kruskal Wallis test in Table 1 shows p-value of C-Reactive Protein levels between group was $<0,001$ ( $p$-value $<0.05$ ), so it can be concluded that there are significant differences of C-Reactive Protein levels between groups.

Exposure to free radicals from tobacco smoke that enters respiratory tract causes body develop defence mechanisms to prevent the impact of cell damage due to oxidative stress (Indraswari et al., 2018). Antioxidant produced in body are enzymatic antioxidants (superoxide dismutase [SOD], glutathione peroxidase [GSH-Px], and catalase), while antioxidant from outside are nonenzymatic antioxidant derived from food intake such as flavonoids (Suryadinata et al., 2016). The balance between number of free radicals and 
Table 1. Levels of C-Reactive Protein in research

\begin{tabular}{|c|c|c|c|c|c|c|c|}
\hline & \multirow[t]{2}{*}{ Group } & \multicolumn{5}{|c|}{$\begin{array}{l}\text { C-Reactive Protein levels } \\
(\mathrm{mg} / \mathrm{L}) \text { in Wistar Rats }\end{array}$} & \multirow{2}{*}{$\begin{array}{c}\text { Kruskal } \\
\text { Wallis Tes }\end{array}$} \\
\hline & & $1^{\mathrm{st}}$ & $2^{\text {nd }}$ & $3^{\text {rd }}$ & $4^{\text {th }}$ & $5^{\text {th }}$ & \\
\hline I & $\begin{array}{l}\text { The negative control group without exposure to cigarette smoke } \\
\text { and intake of red mulberry juice }\end{array}$ & $<6$ & $<6$ & $<6$ & $<6$ & $<6$ & \\
\hline II & $\begin{array}{l}\text { The positive control group received exposure to smoke cigarettes } \\
\text { and no intake of red mulberry juice }\end{array}$ & 48 & 48 & 48 & 24 & 24 & \\
\hline III & $\begin{array}{l}\text { Treatment group I was exposed to cigarette smoke and red } \\
\text { mulberry juice intake of } 3.25 \mathrm{~g}\end{array}$ & 24 & 12 & 12 & $<6$ & $<6$ & $<0.001$ \\
\hline IV & $\begin{array}{l}\text { Treatment group II received smoke exposure cigarettes and red } \\
\text { mulberry juice intake of } 6.5 \mathrm{~g}\end{array}$ & $<6$ & $<6$ & $<6$ & $<6$ & $<6$ & \\
\hline $\mathbf{V}$ & $\begin{array}{l}\text { Treatment group III received smoke exposure cigarettes and red } \\
\text { mulberry juice intake of } 13 \mathrm{~g}\end{array}$ & $<6$ & $<6$ & $<6$ & $<6$ & $<6$ & \\
\hline
\end{tabular}

antioxidants is needed for the stability of body normal metabolic process (Biswas et al., 2017).

Reactive Oxygen Species (ROS) are the most reactive and radical types that directly respond to inflammation in body. These radicals can be neutralized with superoxide dismutase (SOD) into hydrogen peroxidase $(\mathrm{H} 2 \mathrm{O} 2)$ then will be neutralized with glutathione peroxidase (GSH-Px) and catalase into water $(\mathrm{H} 2 \mathrm{O})$ and oxygen $(\mathrm{O} 2)$ (Nimse and Pal, 2015).

However, an increase in excessive free radicals can result in cell damage or necrosis. This process will cause cells to become lysis and is called debris cells (Vénéreau et al., 2015). This will stimulate the movement of macrophages as one mechanism of body defence. Phagocytic process carried by macrophages will trigger secretion of pro-inflammatory cytokines such as interleukin-1, interleukin-6, and tumor necrosis factor-alpha (TNF- $\alpha$ ) (Thomsen et al., 2016). Excessive release of proinflammatory cytokines will induce liver to secrete C-Reactive Protein (Sproston and Ashworth, 2018).

Inflammatory processes in the body have positive and negative effects. In acute and low condition, Inflammatory processes will function as a defence and healing process for cell tissue, while if the condition is chronic, then it will have impact on cell damage. Exposure to cigarette smoke that given regularly and continuously will create chronic inflammatory conditions that have a negative impact on health (Srivastava and Kumar, 2015). Therefore, the administration of antioxidants through food intake is expected to be able to prevent the inflammatory process by decreasing free radicals.

Administration of red mulberry juice (Morus rubra) which rich in flavonoids shows its efficacy on decreasing levels of C-Reactive Protein in blood due to exposure to tobacco smoke. Therefore, the use of red mulberries as an additional intake of antioxidants from outside body can be considered as one way to prevent cell damage due to inflammatory process.

\section{CONCLUSION}

Exposure to tobacco smoke can increase body inflammatory response through increased levels of C-Reactive Protein in the blood. Giving red mulberry juice can reduce the response of inflammation caused by exposure to tobacco smoke in rats.

\section{ACKNOWLEDGEMENT}

The researcher is grateful to all laboratory staff who have assisted the research process.

\section{REFERENCES}

Arulselvan, P., Fard, M. T., Tan, W. S., Gothai, S., Fakurazi, S., Norhaizan, M. E., ... Kumar, S.S. (2016). Role of antioxidants and natural products in inflammation. Oxidative Medicine and Cellular Longevity, 2016, 1-15. doi: $10.1155 / 2016 / 5276130$

Biswas, S., Das, R., \& Ray Banerjee, E. (2017). Role of free radicals in human inflammatory 
diseases. AIMS Biophysics, 4(4), 596-614. doi: 10.3934/biophy.2017.4.596

Gowing, L. R., Ali, R. L., Allsop, S., Marsden, J., Turf, E. E., West, R., \& Witton, J. (2015). Global statistics on addictive behaviours: 2014 status report. Addiction, 110(6), 904-919. doi: 10.1111/add.12899.

Hossain, S., Hossain, S., Ahmed, F., Islam, R., Sikder, T., \& Rahman, A. (2017). Prevalence tobacco smoking and factors associated with the initiation of smoking among university students in Dhaka, Bangladesh. Central Asian Journal of Global Health, 6(1). doi: 10.5195/ cajgh.2017.244

Indraswari, P. I. I., Lorensia, A., and Suryadinata, R. V. (2018). Analysis effect of nutrition intake on lung function of active smoker and non smoker. Jurnal Kesehatan Masyarakat, 14(2), 247-253. Retrieved from https://journal.unnes.ac.id/nju/ index.php/kemas/article/view/14947

Kamceva, G., Arsova-Sarafinovska, Z., Ruskovska, T., Zdravkovska, M., Kamceva-Panova, L., \& Stikova, E. (2016). Cigarette smoking and oxidative stress in patients with coronary artery disease. Open Access Macedonian Journal of Medical Sciences, 4(4), 636. doi: 10.3889/ oamjms.2016.117

Nasser, A., Salah, B., Regassa, L., Alhakimy, A., \& Zhang, X. (2018). Smoking prevalence, attitudes and associated factors among students in health-related Departments of Community College in rural Yemen. Tobacco Induced Diseases, 16(July). doi: 10.18332/tid/92547

Nimse, S. B. \& Pal, D. (2015). Free radicals, natural antioxidants, and their reaction mechanisms. RSC Advances, 5(35), 27986-28006. doi: 10.1039/C4RA13315C

Phaniendra, A., Jestadi, D. B., \& Periyasamy, L. (2015). Free radicals: properties, sources, targets, and their implication in various diseases. Indian Journal of Clinical Biochemistry, 30(1), 11-26. doi: 10.1007/s12291-014-0446-0

Pratiwi, S. R., Lorensia, A., \& Suryadinata, R. V. (2018). Vitamin C and E Intake with SQFFQ towards Smokers' and Non-Smokers' Lung Function. Media Kesehatan Masyarakat Indonesia, 14(2), 101. Retrieved from http:// journal.unhas.ac.id/index.php/mkmi/issue/ view/559

Sproston, N. R., \& Ashworth, J. J. (2018). Role of c-reactive protein at sites of inflammation and infection. Frontiers in Immunology, 9. doi: 10.3389/fimmu.2018.00754

Srivastava, K. K., \& Kumar, R. (2015). Stress, oxidative injury and disease. Indian Journal of Clinical Biochemistry, 30(1), 3-10. doi: 10.1007/s12291-014-0441-5

Suryadinata, Rivan Virlando, Wirjatmadi, B. (2019). The role of selenium micronutrients as antioxidants in exposure to e-cigarette smoke. Asian Journal of Pharmaceutical and Clinical Research, 12(8), 265-268. Retrieved fom https://innovareacademics.in/journals/index. php/ajpcr/issue/view/466

Suryadinata, R. V., Wirjatmadi, B., \& Adriani, M. (2016). Pengaruh perubahan hiperplasia sel goblet selama 28 hari paparan asap rokok dengan pemberian antioksidan superoxide dismutase. The Indonesian Journal of Public Health, 11(1), 60. Retrieved from 10.20473/ ijph.v11i1.2016.60-68

Suryadinata, R. V., Wirjatmadi, B., \& Adriani, M. (2017). Efektivitas penurunan malondialdehyde dengan kombinasi suplemen antioksidan superoxide dismutase melon dan gliadin akibat paparan rokok. Global Medical And Helath Communication, 5(2), 79-83. Retrieved from

Suryadinata, R. V., Wirjatmadi, B., Adriani, M., and Sumarmi, S. (2019). The effects of exposure duration to electronic cigarette smoke on differences in superoxide dismutase and malondialdehyde in blood of wistar rats. International Journal of Current Pharmaceutical Research, 11(3), 13-16. doi: 10.22159/ijcpr.2019v11i3.34084

Thomsen, M., Kersten, C., Sorbye, H., Skovlund, E., Glimelius, B., Pfeiffer, P., et al. (2016). Interleukin-6 and $\mathrm{C}$-reactive protein as prognostic biomarkers in metastatic colorectal cancer. Oncotarget, 7(46), 75013-75022. doi: 10.18632/oncotarget.12601.

Vénéreau, E., Ceriotti, C., and Bianchi, M. E. (2015). DAMPs from cell death to new life. Frontiers in Immunology, 6.

Virlando Suryadinata, R. (2018). Effect of free radicals on inflammatory process in chronic obstructive pulmonary disease (COPD). Amerta Nutrition, 2(4), 317-324. doi: 10.20473/amnt. v2i4.2018.317-324

West, R. (2017). Tobacco smoking: Health impact, prevalence, correlates and interventions. Psychology \& Health, 32(8), 1018-1036. doi: 10.1080/08870446.2017.1325890 
Zhang, H., Ma, Z., Luo, X., \& Li, X. (2018). Effects of mulberry fruit (morus alba 1.) consumption on health outcomes: a mini-review. Antioxidants, 7(5), 69. doi: 10.3390/antiox7050069
Zhang, Z. \& Shi, L. (2010). Anti-inflammatory and analgesic properties of cis-mulberroside $A$ from Ramulus mori. Fitoterapia, 81(3), 214-218. doi: 10.1016/j.fitote.2009.09.005 